\title{
The Hydrochemistry of Groundwater in Jambakan, Klaten Regency, Central Java Province, Indonesia
}

\author{
Ekha Yogafanny ${ }^{1 *}$, Ardian Novianto ${ }^{2}$, Rika Ernawati ${ }^{3}$, Wibiana Wulan Nandari ${ }^{4}$ \\ ${ }^{1}$ Environmental Engineering Department, Faculty of Mineral Technology, Universitas Pembangunan Nasional Veteran Yogyakarta, Indonesia \\ ${ }^{2}$ Geophysics Engineering Department, Faculty of Mineral Technology, Universitas Pembangunan Nasional Veteran Yogyakarta, Indonesia \\ ${ }^{3}$ Mining Engineering Department, Faculty of Mineral Technology, Universitas Pembangunan Nasional Veteran Yogyakarta, Indonesia \\ ${ }^{4}$ Chemical Engineering Department, Faculty of Industrial Engineering, Universitas Pembangunan Nasional Veteran Yogyakarta, Indonesia \\ *Corresponding Email: ekha.yogafanny@upnyk.ac.id \\ Tel.:+62-857-1103-8366 \\ Received: Oct 14, 2019; Accepted: Nov 19, 2019. \\ DOI: 10.25299/jgeet.2019.4.4.3918
}

\begin{abstract}
Jambakan is a hamlet in Bayat District, Central Java Province, Indonesia, which commonly has brackish groundwater. Its unique geological profile leads to variation in groundwater quality that is even found between adjacent wells. This study was designed to identify the quality and hydrochemical type of groundwater and the distribution of brackish groundwater in Jambakan. It employed a quantitative method to analyzethe data collected in the field survey and groundwater quality data (major ions). Meanwhile, the hydrochemical facies of groundwater was interpreted from the plots of major ions on trilinear and quadrilateral Piper diagrams. The results showed that some of the groundwater quality parameters in six wells, namely A6, A34, A38, A65, A67, and A73, had exceeded the standard thresholds. The parameters in question were TDS, EC, salinity, sodium, calcium, chloride, sulfate, magnesium, and hardness. Compared with the six wells, A40 and A45 had better quality. The distribution of brackish groundwater could not be modeled horizontally because salinity highly depends on rock layers where the observed wells are located. Based on the trilinear Piper plots, the groundwater consisted of four hydrochemical facies, namely magnesium bicarbonate, a mixed type, calcium chloride, and sodium chloride. Meanwhile, the quadrilateral Piper diagrams showed the presence of Type I (bicarbonate water), Type II (semi-bicarbonate water), Type III (evaporite water), and Type IVb-IVc (sulfate water) in the groundwater of Jambakan Hamlet.
\end{abstract}

Keywords: brackish water, hydrochemistry, groundwater quality

\section{Introduction}

Water on the Earth is composed of $1.67 \%$ groundwater, $96.5 \%$ seawater, $1.74 \%$ glaciers, and $0.09 \%$ surface water (lakes, swamps, rivers, etc.) Groundwater consists of $44.97 \%$ freshwater and $55.03 \%$ brackish water. Bayat District in Central Java Province, Indonesia has several areas where brackish groundwater prevails and, consequently, the drinking water supply system requires special attention. Understanding the brackish groundwater distribution and groundwater geochemistry in Bayat District becomes necessary, notably in determining appropriate strategies for drinking water provision in regions with brackish groundwater-including Jambakan.

Hard or brackish groundwater is ubiquitous in Jambakan, a village in Bayat District. It has a smaller administrative unit that shares its name, i.e., Jambakan Hamlet. In this hamlet, the population grows rapidly from year to year even though the majority of the well water is brackish and that there is no reliable access to freshwater. Using EC meter for direct measurement in the field, Santosa (2001) claimed that the groundwater in the hamlet has an Electrical Conductivity (EC) of 1,500 - 3,000 $\mu \mathrm{mhos} / \mathrm{cm}$ and Total Dissolved Solids (TDS) upward of $1,000 \mathrm{mg} / \mathrm{L}$, categorizing this groundwater as brackish. Most importantly, the groundwater has uniquely different taste or quality, and such variation is apparent even in neighboring wells.

In 2018, analysis of several test wells proved the presence of brackish groundwater with TDS of 1,416 $\mathrm{mg} / \mathrm{L}$, EC of $2,840 \mu \mathrm{mhos}$, hardness of $740.30 \mathrm{mg} / \mathrm{L}$, chloride content of $426.8 \mathrm{mg} / \mathrm{L}$, sulfate content of $1,596 \mathrm{mg} / \mathrm{L}$, and salinity of $1,467 \%$ (Sari, 2019). In most cases, $\mathrm{Cl}-, \mathrm{Ca}, \mathrm{Mg}$, and $\mathrm{Na}$ ions make up the chemical composition of brackish water. Consuming it or water containing salt minerals for a long time can disturb human health. Also, if used for watering crops, brackish water is likely to result in lower yields than freshwater (Astuti et al., 2006). According to the Head of Jambakan Village, the residents have been experiencing the negative impact of the current groundwater situation on their daily activities, especially bathing, washing, and cleansing after urination and defecation. Nowadays, some residents of Jambakan Hamlet have access to clean water for consumption from a governmentowned water company (PDAM). As for bathing, washing, and cleansing, they still use brackish groundwater. 
Providing safe water for consumption and use is one of the objectives in the Sustainable Development Goals (SDGs). For this reason, brackish water must be treated first before use, and its uneven distribution in Jambakan Hamlet needs to be identified as an attempt to develop the appropriate groundwater management model for the community. This research is expected to be able to address the problem of brackish groundwater on a household scale and then be replicated in other areas with similar issues. Therefore, this study attempted to:

a) Determine the groundwater quality and the distribution of brackish groundwater in the study area

b) Identify the hydrochemical facies of groundwater in the study area by analyzing the generated trilinear and quadrilateral Piper diagrams

\section{Methods}

This research employed a quantitative method as a basic approach to analyzing a set of data collected by survey and interviews. The survey aimed to identify and measure or quantify the condition in the field, mainly the groundwater quality (total dissolved solids/TDS), and the results were presented in maps. Meanwhile, the interview was intended to find out the temporal condition of brackish water, such as water quality fluctuations from time to time and in rainy and dry seasons.

Aside from survey and interview, this study also used a mathematical method, namely the Piper diagram (trilinear and rectangular). These methods helped to determine the hydrochemical facies of groundwater in Jambakan Hamlet. The values or levels of the groundwater quality parameters were obtained through laboratory tests and later analyzed with a quantitative descriptive approach to achieve the research objectives. These methods used the concentration of anions and cations in the water samples collected from eight groundwater wells. These eight wells were determined by considering the concentration of TDS that was measured in the entire wells in study area. The TDS was measured directly using the portable tools namely
TDSmeter.Based on the measured TDS, the groundwater was subjected to judgment sampling. In this technique, researchers decide which samples are most representative of the population or the study area based on the predefined research objectives. The groundwater was physically sampled from ten wells in Jambakan Hamlet, and these wells were selected based on the classification of the measured TDS, namely <1,000 mg/L, 1,000-2,000 $\mathrm{mg} / \mathrm{L}$, and $2,000-3500 \mathrm{mg} / \mathrm{L}$.

The hydrochemical analysis used trilinear and rectangular Piper diagrams that were generated using "Grapher" software. These diagrams indicated the hydrochemical type of groundwater by tracing the dominant ion contents. The eight groundwater samples were analyzed based on the concentrations of major cations and anions. The major cations consisted of $\mathrm{K}^{+}, \mathrm{Mg}^{2+}, \mathrm{Na}^{+}$, and $\mathrm{Ca}^{2+}$, while the major anions were $\mathrm{Cl}^{-}, \mathrm{SO}_{4}^{-}, \mathrm{HCO}_{3}{ }^{-}$, and $\mathrm{CO}_{3}{ }^{\circ}$

Grapheris a software used to plot wells on trilinear Piper diagrams with the following steps:

a. Inputting the concentrations of all major cations and anions based on the laboratory analysis results to a spreadsheet program (e.g., Microsoft Excel),

b. Converting the unit of measurement of each major ion from $\mathrm{mg} / \mathrm{L}$ to $\mathrm{meq} / \mathrm{l}$ and percent (the trilinear diagram uses percent), and

c. Inputting the converted data (in percent) to Grapher according to the placement of the major ions.

Afterward, the software processed the data and produced a Piper plot, namely a diagram consisting of two equilateral triangles on the lower-right (cations) and lower-left (anions). Above these triangles are parallelograms, which is the meeting points or projections of the cation and anion triangles. The positions of the data points in this parallelogram were interpreted as the type of groundwater quality.

With this method, the percentages of cations and anions in the groundwater samples were drawn in Piper plots, and the chemical properties were identified by defining the dominant groups of ions in the parallelogram, as seen in Figure 2.1.

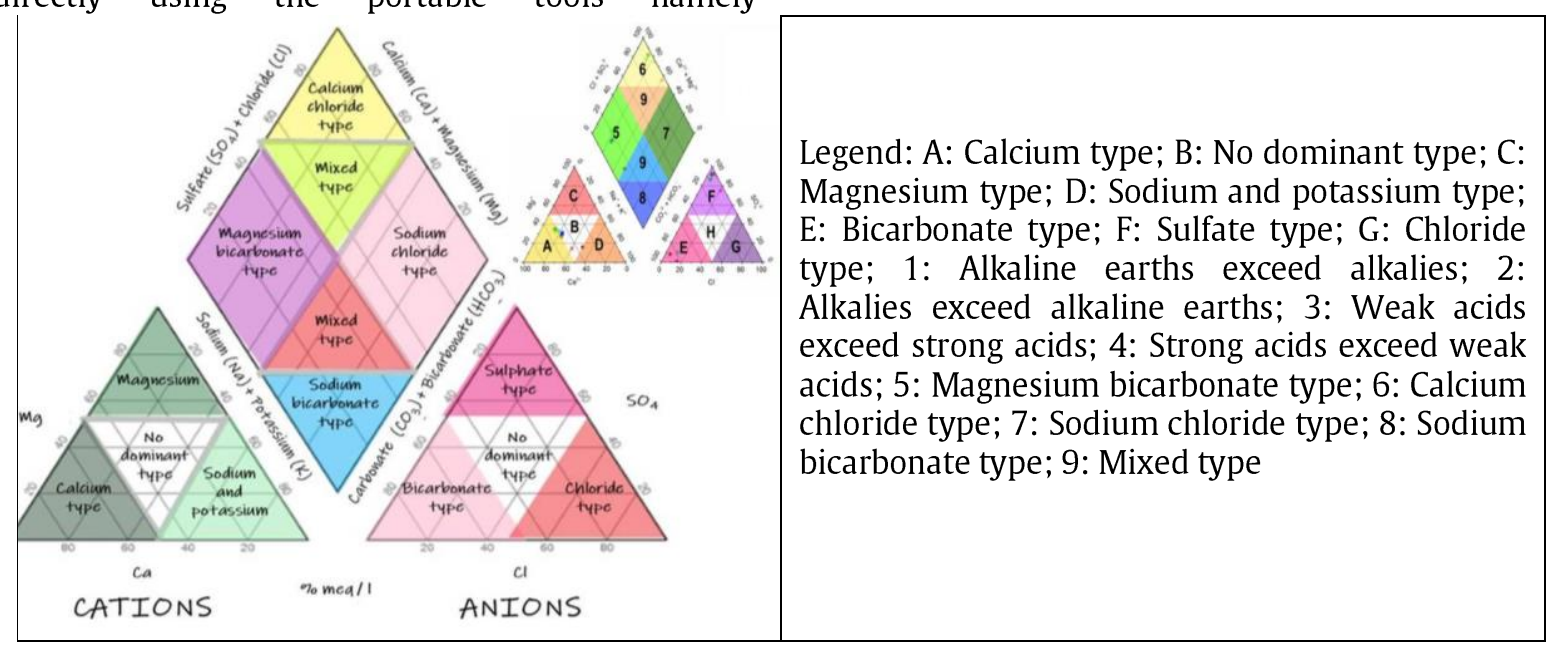

Fig 1. The Hydrochemical Facies of Groundwater Based on Trilinear Piper Diagram 
diagram uses.The trilinear Piper diagram classifies dominant ions in groundwater based on the division of the parallelogram area into nine fields, as seen in Figure 2.2. Each field marks the hydrochemical facies of the plotted data points (Suharyadi, 1984).

Field (1) means that alkaline earths exceed alkalies.

Field (2) means that alkalies exceed alkaline earths.

Field (3) means that weak acids exceed strong acids. Field (4) means that strong acids exceed weak acids.

Field (5) represents hardness with carbonates (secondary alkalinity) higher than $50 \%$, meaning that alkaline earths and weak acids dominate the groundwater.

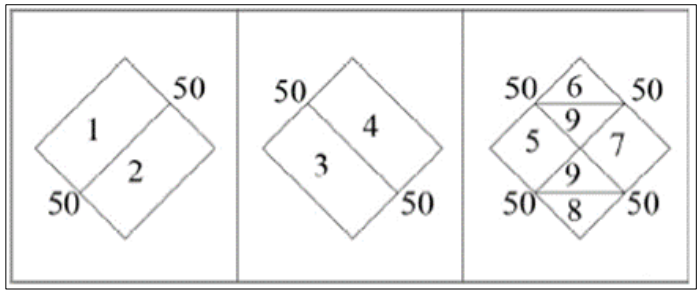

Figure 2. The Division of the Parallelogram Area in the Trilinear Piper Diagram into Several Fields (Source: Walton, 1970 in Suharyadi, 1984)

Field (6) represents hardness with non-carbonates (secondary alkalinity) higher than $50 \%$.

Field (7) means that the non-carbonate alkalies (primary salinity) are upward of 50\% and that alkalies and strong acids dominate the groundwater.
Field (8) represents carbonate alkalies (primary alkalinity) of more than $50 \%$.

Field (9) indicates balanced cation-anion pairs; no groups of ions exceed $50 \%$.

The hydrochemical analysis also involved a rectangular Piper diagram adapted from Kloosterman (1983), as seen in Figure 2.3. The Kloosterman or rectangular Piper Diagram classified groundwater into six (6) hydrochemical types. Types 1 (bicarbonate water) and 2 (semi-bicarbonate water) are tasteless and, therefore, suitable as the source of raw and clean water. Type- 1 groundwater is usually found in fluvial landform units, while Type-2 groundwater is common in flood plains or the results of fluvial sedimentation. As for Type 3, it is evaporate water with brackish to salty taste. This water is formed due to the dissolution of crystals of mineral salts present in rocks or aquifers. The salt crystals can come from ancient seawater that is trapped on land and evaporates, leaving the salt crystals in rocks. This type of water indicates that the land was previously part of the seafloor that rose during uplift. Type 4 or sulfate water is groundwater with high sulfate content and brackish to salty taste. Type 5 is fossil or connate water, which has high dissolved mineral salts (TDS) caused by the exchange of ions between groundwater and parent rocks following prolonged contact between the two materials. Type 6 or intrusion water typifies groundwater that comes from the process of seawater intrusion (Santosa, 2010).

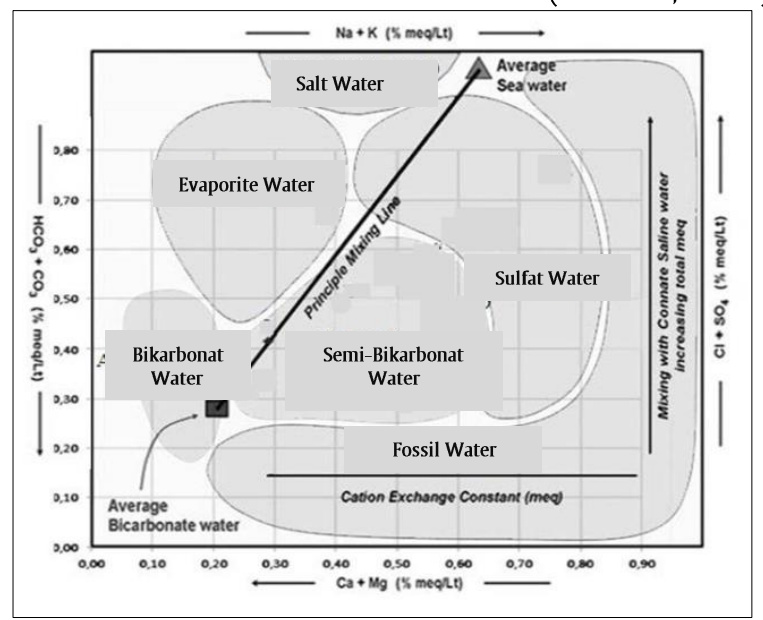

Fig 2. The Hydrochemical Type of Groundwater Based on Rectangular Piper Diagram

The genesis of the brackish groundwater in the study area was analyzed using quantitative and qualitative descriptive techniques. The former was based on the water quality data and hydrochemical profiles that had been plotted on the Piper diagram, while the latter involved a study of literature related to groundwater hydrochemistry, the geological and geomorphological processes of Bayat District, geoelectrical data, and the depth of the test wells.

\section{Results and Discussion}

\subsection{Groundwater Quality Analysis and Brackish Groundwater Distribution}

The research took place in Jambakan Hamlet. There are 75 dug wells used by the residents to meet their daily water needs (i.e., bathing, washing, and cleansing after defecation and urination). The groundwater samples were collected from eight dug wells and tested in the laboratory of BBTKLPP Yogyakarta. The measured parameters were compared with the water quality standards set in the Government Regulation No. 82 of 2001 for Class 1 water management and pollution control, the Regulation of the Ministry of Health No. 416/MEN.KES/PER/IX/1990 on the requirements and supervision of water quality, and the Decree of the Ministry of Health No. 32 of 2017 on environmental health and the requirements of safe water for hygiene, sanitation, swimming pool, solus per aqua, and public baths. 
As presented in Table 3.1., several parameters had exceeded their allowable presence, especially in Wells A6, A34, A38, A65, A67, and A73. These parameters included TDS, EC, salinity, sodium, calcium, chloride, sulfate, magnesium, and hardness. Based on the laboratory test results and the above regulations, A40 and $\mathrm{A} 45$ have better groundwater quality than the six other wells.

Table 1. The Hydrochemical Profile of the Groundwater in Jambakan Hamlet

\begin{tabular}{|c|c|c|c|c|c|c|c|c|c|c|}
\hline Parameters & Units & A6 & A34 & A38 & A40 & A45 & A65 & A67 & A73 & $\begin{array}{c}\text { Standar } \\
\text { ds }\end{array}$ \\
\hline TDS & $\mathrm{mg} / \mathrm{L}$ & 3295 & 645 & 935 & 466 & 438 & 2556 & 1299 & 1299 & $1000^{*}$ \\
\hline $\mathrm{EC}$ & $\mu \mathrm{S} / \mathrm{cm}$ & 6456 & 1194 & 1900 & 892 & 836 & 5851 & 3023 & 2591 & $1500^{*}$ \\
\hline TSS & $\mathrm{mg} / \mathrm{L}$ & 1 & 1 & 2 & 2 & 3 & 1 & 1 & 1 & $50^{*}$ \\
\hline Salinity & $\%$ & 3.3 & 0.6 & 0.9 & 0.5 & 0.4 & 2.6 & 1.3 & 1.4 & $0.5^{* * *}$ \\
\hline Turbidity & NTU & 1.1 & 0.6 & 0.8 & 0.4 & 0.6 & 1 & 0.5 & 0.6 & $25^{* *}$ \\
\hline $\begin{array}{l}\text { Manganese(M } \\
\text { n) }\end{array}$ & $\mathrm{mg} / \mathrm{L}$ & $<0.0101$ & $<0.0101$ & $\begin{array}{c}<0.010 \\
1\end{array}$ & $\begin{array}{c}<0.010 \\
1\end{array}$ & $\begin{array}{c}<0.010 \\
1\end{array}$ & $<0.0101$ & $\begin{array}{c}<0.010 \\
1\end{array}$ & $\begin{array}{c}<0.010 \\
1\end{array}$ & $0.1^{*}$ \\
\hline Iron $(\mathrm{Fe})$ & $\mathrm{mg} / \mathrm{L}$ & 0.0369 & 0.0558 & $\begin{array}{c}<0.016 \\
2\end{array}$ & $\begin{array}{c}<0.016 \\
2\end{array}$ & 0.0275 & $<0.0162$ & 0.0369 & $\begin{array}{c}<0.016 \\
2\end{array}$ & $0.3^{*}$ \\
\hline $\operatorname{Zinc}(\mathrm{Zn})$ & $\mathrm{mg} / \mathrm{L}$ & $<0.0083$ & $<0.0083$ & $\begin{array}{c}<0.008 \\
3\end{array}$ & $\begin{array}{c}<0.008 \\
3\end{array}$ & $\begin{array}{c}<0.008 \\
3\end{array}$ & $<0.0083$ & $\begin{array}{c}<0.008 \\
3\end{array}$ & $\begin{array}{c}<0.008 \\
3\end{array}$ & $0.05^{*}$ \\
\hline Natrium (Na) & $\mathrm{mg} / \mathrm{L}$ & 398 & 133 & 259 & 36 & 44 & 214 & 267 & 280 & $200^{* * *}$ \\
\hline Potassium (K) & $\mathrm{mg} / \mathrm{L}$ & 4 & 3 & 5 & 4 & 4 & 9 & 4 & 10 & - \\
\hline Calcium (Ca) & $\mathrm{mg} / \mathrm{L}$ & 329.64 & 92.46 & 86.43 & 120.6 & 102.91 & 317.58 & 112.56 & 137.48 & $\begin{array}{c}75- \\
200^{* * *}\end{array}$ \\
\hline Bicarbonate & $\mathrm{mg} / \mathrm{L}$ & 345 & 400 & 460 & 260 & 439.2 & 634.4 & 267.5 & 385 & - \\
\hline $\mathrm{HCO}_{3}$ & $\mathrm{mg} / \mathrm{L}$ & 420.9 & 488 & 561.2 & 317.2 & 360 & 520 & 326.3 & 469.7 & - \\
\hline Chloride $(\mathrm{Cl})$ & $\mathrm{mg} / \mathrm{L}$ & 614.8 & 87.5 & 164.9 & 56 & 34 & 704.8 & 409.9 & 189.9 & $600^{*}$ \\
\hline Sulfate (SO4) & $\mathrm{mg} / \mathrm{L}$ & 1860 & 264 & 398 & 134 & 138 & 1231 & 499 & 760 & $400^{*}$ \\
\hline $\mathrm{pH}$ & - & 7.3 & 7.2 & 7.4 & 7.4 & 7.4 & 7.2 & 7.1 & 7.4 & $6-9 *$ \\
\hline $\begin{array}{l}\text { Magnesium } \\
(\mathrm{Mg})\end{array}$ & $\mathrm{mg} / \mathrm{L}$ & 170.96 & 8.31 & 14.41 & 28.33 & 24.42 & 114.79 & 82.06 & 52.27 & $150^{* * *}$ \\
\hline $\begin{array}{l}\text { Hardness } \\
\left(\mathrm{CaCO}_{3}\right)\end{array}$ & $\mathrm{mg} / \mathrm{L}$ & 1527.64 & 265.33 & 275.38 & 418.09 & 357.79 & $\begin{array}{c}1266.3 \\
3\end{array}$ & 619.1 & 558.79 & $500^{* * * *}$ \\
\hline Well depth & $\mathrm{m}$ & 10.49 & 9.4 & 7.58 & 8.03 & 15.21 & 10.16 & 11.45 & 14.12 & \\
\hline
\end{tabular}

Source: Field Survey in June 2019

Notes: Gray-colored cells mark parameters that exceed the benchmarks or standards

*Government Regulation No. 82 of 2001 on the management and pollution control of Class 1 water (raw water for drinking)

** Regulation of the Ministry of Health No 416/MEN.KES/PER/IX/1990 on the requirements and supervision of water quality

****Water quality standards according to Effendi, 2003 and Suharyadi, 1984

**** Decree of the Ministry of Health No. 32 of 2017 environmental health and the requirements of safe water for hygiene, sanitation, swimming pool, solus per aqua, and public baths

The groundwater quality analysis in the study area focused on parameters that exceeded the quality standards. The first parameter is Total Dissolved Solids(TDS), which in liquid substances, are composed of organic matters, inorganic salts, and dissolved gases. The higher the TDS, the higher the electrical conductivity is in the water. Because TDS depends on the number of dissolved salts in the water, it also represents the hardness and salinity of the eight sampled wells in the study area. Analysis of solids in water is useful for creating a complete profile of water composition and, consequently, planning and supervising clean water and wastewater treatment (Alaerts and Santika, 1987). Water classification based on Total Dissolved Solids (TDS) is presented in Table 3.2.

Table 2.The Criteria of Salinity Based on Total Dissolved Solids (TDS)

\begin{tabular}{ccl}
\hline No, & TDS $(\mathrm{mg} / \mathrm{L})$ & Levels of Salinity \\
\hline 1 & $0-1,000$ & Freshwater \\
2 & $1,001-3,000$ & Slightly saline \\
3 & $3,001-10,000$ & Moderately saline \\
4 & $10,001-100,000$ & Saline \\
5 & $>100,000$ & Brine \\
\hline
\end{tabular}

(Source: Mc Neely et al. in Effendi, 2003)
Figure 3.1 presents the TDS measured in eight sampled wells. TDS was found upwards of $1,000 \mathrm{mg} / \mathrm{L}$ in four wells, namely A6, A65, A67, and A73. A6 contained $3,295 \mathrm{mg} / \mathrm{L}$ of dissolved solids and were categorized as moderately saline groundwater. Meanwhile, the TDS of A65, A67, and A73 were 2,556 $\mathrm{mg} / \mathrm{L}, 1,299 \mathrm{mg} / \mathrm{L}$, and $1,299 \mathrm{mg} / \mathrm{L}$, respectively, indicating the presence of slightly saline or brackish groundwater.

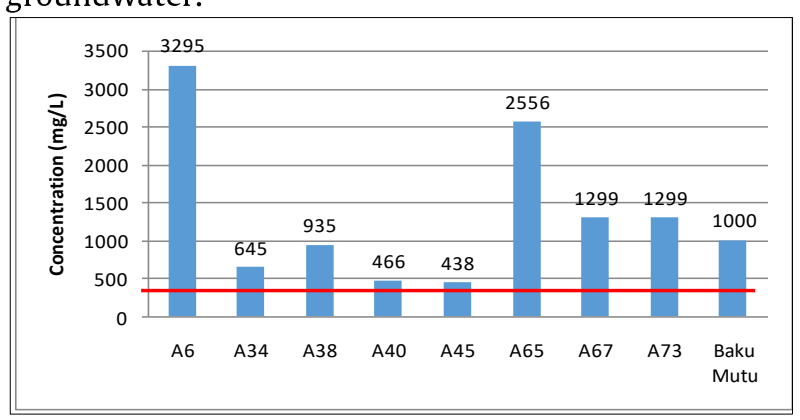

Fig 3. The Total Dissolved Solids (TDS) of Groundwater in Eight Sampled Wells in Jambakan Hamlet

Salinity represents the amount of salt content dissolved in water. Water is brackish or saline when its salinity is greater than $0.5 \%$. Water salinity is classified into three, namely freshwater $(0-0.5 \%)$, 
brackish water $(0.5-30 \%)$, and sea or saltwater ( $>30$ $\%$ o). The salinity in the groundwater is controlled by the precipitation,evaporation, mineralogy, type of aquifers, topography, and seawater intrusion (Fatoni, et.al., 2018). The results of the groundwater quality analyses in Jambakan Hamlet are summarized in Figure 3.2. Six wells were identified with the salinity of higher than $0.5 \%$, namely A6 (3.3\%o), A34 (0.6\%), A38 (0.9\%o), A65 (2.6\%), A67 (1.3\%), and A73 (1.4\%), and classified as brackish. Also, the groundwater samples with high salinity levels $(>0.5 \%$ ) or brackish water had TDS $>1,000 \mathrm{mg} / \mathrm{L}$. Unlike the six wells, A34 and A38 contained groundwater with salinity $>0.5 \%$ but TDS $<1,000 \mathrm{mg} / \mathrm{L}$. Nevertheless, these findings are considered insignificant in groundwater classification because direct measurements in the field have proven that the groundwater in both wells is brackish. Groundwater that is categorized as brackish because of high salinity or high TDS is not suitable as a source of raw water. Treatment to reduce levels of dissolved salts in the water is required before public consumption or use.

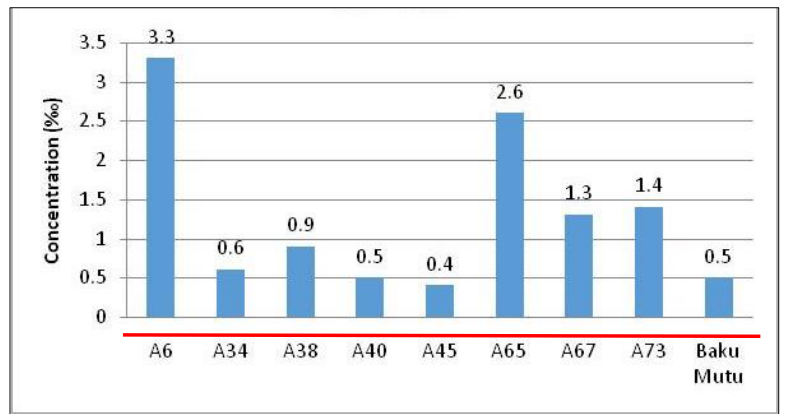

Fig 4. The Salinity Levels of Groundwater in Eight Sampled Wells in Jambakan Hamlet

Hardness or $\mathrm{CaCO}_{3}$ content is an indication of lime in groundwater. Hardness can cause problems for households as it gradually forms crusts on the kettle and water pipes, potentially blocking and further contaminating distributed raw water. According to the Regulation of the Ministry of Health No. 32 of 2017 on environmental quality standards, water is safe for consumption when its hardness is not above 500 $\mathrm{mg} / \mathrm{L}$. The results of the groundwater hardness testing in Jambakan Hamlet are depicted in Figure 3.3. Wells A6, A65, A67, and A73 contained groundwater with high $\mathrm{CaCO}_{3}$ contents, i.e., 1,527.64, 1,266.33, 619.1, and $558.79 \mathrm{mg} / \mathrm{L}$, respectively. Hardness is directly

In this study, major ion contents were used to define the hydrochemical properties of the groundwater samples.The percentages of cations and anions were plotted as data points into trilinear Piper diagrams, as seen in Figure 3.4. There are four hydrochemical types of groundwater in Jambakan Hamlet, namely magnesium bicarbonate, a mixed type, calcium chloride, and sodium chloride.

The magnesium-bicarbonate facieswas found in Wells A40 and A45. This type of groundwater has a hardness level or carbonates content (secondary alkalinity) of more than $50 \%$ and is dominated by its alkaline earths, i.e., magnesium $(\mathrm{Mg})$ and calcium $(\mathrm{Ca})$, and weak acids. A40 and A45 were filled with proportional to TDS. These findings prove that the dissolved salts in the groundwater are composed of, among which, $\mathrm{CaCO}_{3}$ or carbonate. High TDS is also attributable to high salt ions dissolved in groundwater, which in this case, the concentrations of sodium, sulfate, calcium, chloride, and magnesium that have exceeded the maximum benchmarks, as presented in Table 3.1. Groundwater with high levels of hardness is not suitable for consumption unless preceded with proper treatment.

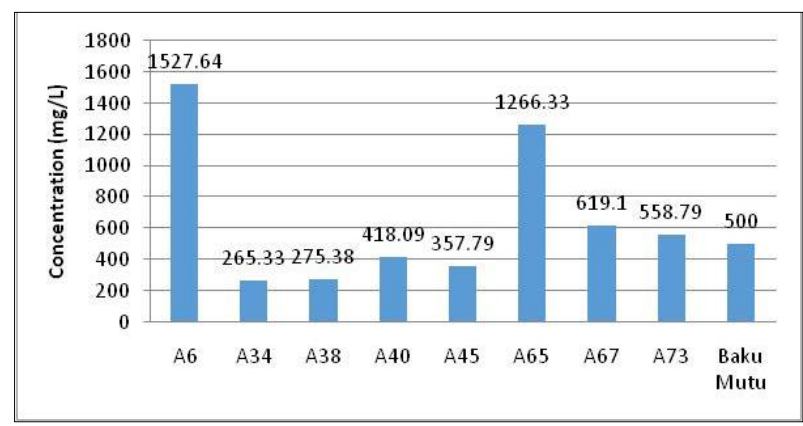

Fig 5. The Hardness Levels of Groundwater in Eight Sampled Wells in Jambakan Hamlet

The thickness and distribution of the clay layers significantly differ from one place to another. The geological conditions and subsurface rock stratigraphy strongly influence the formation of clay layers. Although the study area has flat to gently sloping morphology, the subsurface rock layers are not homogeneous because swamp deposits in the past control the process of the rock formation (clay sediments) (Rahardjo, 2000 and Mulyaningsih et al., 2006).

\subsection{The Hydrochemical Facies of Groundwater}

Based on laboratory test results, five of the eight sampled wells had brackish groundwater, with TDS $>1,500 \mathrm{mg} / \mathrm{L}$. The concentrations of the major groundwater cations $\left(\mathrm{Na}^{+}, \mathrm{K}^{+}, \mathrm{Ca}^{2+}\right.$, and $\left.\mathrm{Mg}^{2+}\right)$ and anions $\left(\mathrm{HCO}_{3}{ }^{-}, \mathrm{CO}_{3}{ }^{-}, \mathrm{Cl}\right.$, and $\left.\mathrm{SO}_{4}^{-}\right)$in Jambakan Hamlet are listed in Table 3.3. The hydrochemical type of the groundwater was analyzed from the trilinear Piper diagrams generated in Grapher software and rectangular Piper diagrams (Kloosterman).

\subsubsection{TheHydrochemical Facies of Groundwater Based on the Trilinear Piper Diagrams}

groundwater containing 28.33 and $24.42 \mathrm{mg} / \mathrm{L}$ of Mgand 120.6 and $102.91 \mathrm{mg} / \mathrm{L}$ of Ca. Both cations were dominant but did not exceed their allowable presence in clean water, producing tasteless and good-quality groundwater. Moreover, this type of groundwater has low salinity and TDS.

A mixed type was detected in Well A34. This facies indicates that the cation-anion pairs are balanced and do not exceed $50 \%$. Compared with the other wells, A34 contained groundwater with low dissolved solids and smaller cation and anion concentrations. Based on the laboratory test results, this groundwater had $0.6 \%$ salinity or slightly above the maximum salinity in the water quality standards, i.e., $0.5 \%$. A higher sodium 
(Na) concentration (133 mg/L) than Wells A40 and A45 are believed to be the cause of the salinity in Well A34 (this high Na content does not exceed the water quality benchmark, that is, $200 \mathrm{mg} / \mathrm{L}$ ). However, measurement in the field showed that the groundwater in Well A34 was tasteless.

The calcium-chloride facies was identified in Wells A6 and A65, with total dissolved solids of 3,295 mg/L and 2,556 $\mathrm{mg} / \mathrm{L}$, respectively. This type of groundwater has non-carbonate hardness (secondary salinity) of higher than $50 \%$, as evident from the high sulfate contents $(A 6=1,860 \mathrm{mg} / \mathrm{L} ; A 65=1,231 \mathrm{mg} / \mathrm{L})$. Non-carbonate hardness represents the amount of hardness due to the excess of carbonate hardness and is the difference between total hardness and carbonate hardness. Non-carbonate hardness binds to sulfate and nitrate (anions). Wells A6 and A65 had very high levels of hardness, i.e., $1,527.64 \mathrm{mg} / \mathrm{L}$ and $1,266.33 \mathrm{mg} / \mathrm{L}$, respectively. Groundwater with calcium-chloride facies is brackish and does not meet the clean water requirements. Direct consumption or use is not advised unless preceded with proper water treatment.

The sodium-chloride facies was identified in Wells A38, A67, and A73, with total dissolved solids of 935 , 1,299 , and $1,299 \mathrm{mg} / \mathrm{L}$, respectively. This type of groundwater is brackish and contains non-carbonate alkali (primary salinity) of more than $50 \%$. It is dominated by metal alkalis, i.e., sodium $(\mathrm{Na})$ and potassium $(\mathrm{K})$, and strong acids. The sodium (Na) concentrations in Wells A38, A67, and A73 were 259, 267, and $280 \mathrm{mg} / \mathrm{L}$, while the potassium (K) levels were 5,4 , and $10 \mathrm{mg} / \mathrm{L}$, respectively.

Table 3. The Hydrochemical Types of the Groundwater in Jambakan Hamlet

\begin{tabular}{|c|c|c|c|c|c|c|c|c|}
\hline Parameters & A6 & A34 & A38 & A40 & A45 & A65 & A67 & A73 \\
\hline $\mathrm{Na}(\mathrm{mg} / \mathrm{L})$ & 398 & 133 & 259 & 36 & 44 & 214 & 267 & 280 \\
\hline $\mathrm{K}(\mathrm{mg} / \mathrm{L})$ & 4 & 3 & 5 & 4 & 4 & 9 & 4 & 10 \\
\hline $\mathrm{Ca}(\mathrm{mg} / \mathrm{L})$ & 329.64 & 92.46 & 86.43 & 120.6 & 102.91 & 317.58 & 112.56 & 137.48 \\
\hline $\mathrm{Mg}(\mathrm{mg} / \mathrm{L})$ & 170.96 & 8.31 & 14.41 & 28.33 & 24.42 & 114.79 & 82.06 & 52.27 \\
\hline $\mathrm{Cl}(\mathrm{mg} / \mathrm{L})$ & 614.8 & 87.5 & 164.9 & 56 & 34 & 704.8 & 409.9 & 189.9 \\
\hline $\mathrm{HCO}_{3}(\mathrm{mg} / \mathrm{L})$ & 420.9 & 488 & 561.2 & 317.2 & 360 & 520 & 326.3 & 469.7 \\
\hline $\mathrm{CO}_{3}(\mathrm{mg} / \mathrm{L})$ & 0 & 0 & 0 & 0 & 0 & 0 & 0 & 0 \\
\hline $\mathrm{SO}_{4}(\mathrm{mg} / \mathrm{L})$ & 1860 & 264 & 398 & 134 & 138 & 1231 & 499 & 760 \\
\hline \multirow[t]{3}{*}{$\begin{array}{l}\text { Hydrochemica } \\
1 \text { facies based } \\
\text { on trilinear } \\
\text { Piper diagrams }\end{array}$} & $\begin{array}{l}\text { Calcium } \\
\text { Chloride } \\
\text { Type }\end{array}$ & $\begin{array}{l}\text { Mixed } \\
\text { Type }\end{array}$ & $\begin{array}{l}\text { Sodium } \\
\text { Chloride } \\
\text { Type }\end{array}$ & $\begin{array}{l}\text { Magnesiu } \\
\text { m } \\
\text { Bicarbonat } \\
\text { e Type }\end{array}$ & $\begin{array}{l}\text { Magnesiu } \\
\text { m } \\
\text { Bicarbonat } \\
\text { e Type }\end{array}$ & $\begin{array}{l}\text { Calcium } \\
\text { Chloride } \\
\text { Type }\end{array}$ & $\begin{array}{l}\text { Sodium } \\
\text { Chloride } \\
\text { Type }\end{array}$ & $\begin{array}{l}\text { Sodium } \\
\text { Chloride } \\
\text { Type }\end{array}$ \\
\hline & $\begin{array}{l}\text { Non- } \\
\text { carbonate } \\
\text { hardness } \\
\text { (secondary } \\
\text { salinity) } \\
\text { exceeds } 50 \\
\%\end{array}$ & $\begin{array}{l}\text { None of } \\
\text { the } \\
\text { cation } \\
\text { and } \\
\text { anion } \\
\text { pairs } \\
\text { exceeds } \\
50 \%\end{array}$ & $\begin{array}{l}\text { Non- } \\
\text { carbonate } \\
\text { alkali } \\
\text { (primary } \\
\text { salinity) } \\
\text { exceeds } \\
50 \%\end{array}$ & $\begin{array}{l}\text { Carbonate } \\
\text { hardness } \\
\text { (secondary } \\
\text { alkalinity) } \\
\text { exceeds50 } \\
\%\end{array}$ & $\begin{array}{l}\text { Carbonate } \\
\text { hardness } \\
\text { (secondary } \\
\text { alkalinity) } \\
\text { exceeds50 } \\
\%\end{array}$ & $\begin{array}{l}\text { Non- } \\
\text { carbonate } \\
\text { hardness } \\
\text { (secondary } \\
\text { salinity) } \\
\text { exceeds } 50 \\
\%\end{array}$ & $\begin{array}{l}\text { Non- } \\
\text { carbonate } \\
\text { alkali } \\
\text { (primary } \\
\text { salinity) } \\
\text { exceeds } \\
50 \%\end{array}$ & $\begin{array}{l}\text { Non- } \\
\text { carbonate } \\
\text { alkali } \\
\text { (primary } \\
\text { salinity) } \\
\text { exceeds } \\
\text { 50\% }\end{array}$ \\
\hline & $\mathrm{Ca}-\mathrm{Na}-\mathrm{Cl}$ & $\begin{array}{l}\mathrm{Ca}-\quad \mathrm{Na}- \\
\mathrm{HCO}-\mathrm{Cl}\end{array}$ & $\begin{array}{l}\mathrm{Na}- \\
\mathrm{HCO} 3-\mathrm{Cl}\end{array}$ & $\begin{array}{l}\mathrm{Ca}-\mathrm{HCO}_{3}- \\
\mathrm{Cl}\end{array}$ & $\mathrm{Ca}-\mathrm{HCO} 3$ & $\mathrm{Ca}-\mathrm{Cl}$ & $\mathrm{Ca}-\mathrm{Na}-\mathrm{Cl}$ & $\mathrm{Ca}-\mathrm{Na}-\mathrm{Cl}$ \\
\hline $\begin{array}{l}\text { Hydrochemica } \\
1 \text { facies based } \\
\text { on rectangular } \\
\text { Piper diagrams } \\
\text { (Kloosterman) }\end{array}$ & $\begin{array}{l}\text { Type III, } \\
\text { Evaporite } \\
\text { Water }\end{array}$ & $\begin{array}{l}\text { Type II, } \\
\text { Semi- } \\
\text { bicarbon } \\
\text { ate } \\
\text { Water }\end{array}$ & $\begin{array}{l}\text { Type IVb, } \\
\text { Sulfate } \\
\text { Water }\end{array}$ & $\begin{array}{l}\text { Type I, } \\
\text { Bicarbonat } \\
\text { e Water }\end{array}$ & $\begin{array}{l}\text { Type II, } \\
\text { Semi- } \\
\text { bicarbonat } \\
\text { e Water }\end{array}$ & $\begin{array}{l}\text { Type III, } \\
\text { Evaporite } \\
\text { Water }\end{array}$ & $\begin{array}{l}\text { Type IVc, } \\
\text { Sulfate } \\
\text { Water }\end{array}$ & $\begin{array}{l}\text { Type IVc, } \\
\text { Sulfate } \\
\text { Water }\end{array}$ \\
\hline Taste & Brackish & Tasteless & Brackish & Tasteless & Tasteless & Brackish & Brackish & Brackish \\
\hline
\end{tabular}

Source: Field survey and data analysis (June 2019) 


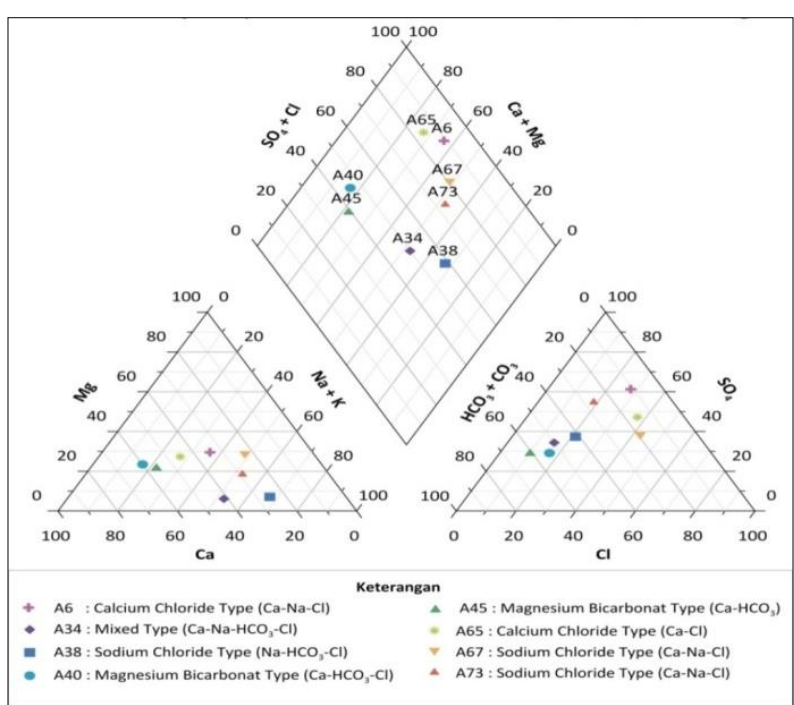

Fig 6. The Hydrochemical Type of Groundwater in Jambakan Hamlet (Trilinear Piper Diagrams)

\subsubsection{The Hydrochemical Facies of Groundwater Based on the Rectangular Piper Diagrams}

Similar to the trilinear Piper diagrams, the rectangular ones also relied on major ion contents to characterize the groundwater hydrochemistry in Jambakan Hamlet. These rectangular or quadrilateral diagrams show scattered plots of the percentages of cations and anions, as seen in Figure 3.5. Table 3.4 presents the four hydrochemical types of groundwater in the study area, namely Type I (bicarbonate water), Type II (semi-bicarbonate water), Type III (evaporate water), and Type IV (sulfate water).

Type I or bicarbonate water was found in Well A40. This type of groundwater has dominant $\mathrm{Ca}-\mathrm{HCO}_{3}-$ Clion contents. Also, it is tasteless and has the best quality among the observed wells in the study area. Aside from Type I, Type II or semi-bicarbonate water is also tasteless and suitable for consumption. Type-II groundwater was detected in Wells A40 and A45. The lateral distribution of fresh groundwater was not easily modeled. With close distance to brackish groundwater, morphological variations on the surface do not directly affect or control groundwater quality. Wells A40, A34, and A45 had different depths, namely $8.03,9.4$, and $15.21 \mathrm{~m}$, indicating that the presence or absence of fresh groundwater does not depend on the depth of the well but rather on the type of waterbearing rock layer at the bottom of the well. Interpretation of geoelectric data revealed clay layers $70 \mathrm{~m}$ below the surface. Also, within the depth of 0-70 $\mathrm{m}$, several layers of sand or alluvium deposits from the young Merapi rock formation were found with a thickness of 1-2 $\mathrm{m}$ and non-uniformly distributed throughout the study area. These alluvium layers are believed to be the source of freshwater in the local domestic wells.

Type III or evaporate water was found in Wells A6 and A65. This type of groundwater is brackish and high salt content, as evident from the high levels of TDS and EC. The dominant ion compositions were Ca$\mathrm{Na}-\mathrm{Cl}$ (Well A6) and $\mathrm{Ca}-\mathrm{Cl}$ (Well A65). Well A6 had a large $\mathrm{Cl}$ concentration $(614.8 \mathrm{mg} / \mathrm{L})$, and Well $\mathrm{A} 65$ had the highest (704.8 mg/L). A high level of $\mathrm{Cl}$ in Type-III groundwater is attributable to the dissolution of mineral salt crystals that are trapped during the process of sedimentary rock formation in the dry period (Todd, 1980). Areas with this type of groundwater may have been in the marine environment in the past. In Jambakan Hamlet, evaporate groundwater is potentially stored in rock layers where salt crystals from ancient seawater settled on limestone and trapped beneath the young volcanic alluvium deposits from Mt. Merapi. After prolonged contact between rocks and groundwater, the salt crystals dissolve and pollute the surrounding groundwater (Santosa, 2001).

Sulfate water or Type IVb-cwas found in Wells A38, A67, and A73. The dominant ion compositions were $\mathrm{Na}-\mathrm{HCO}_{3}-\mathrm{Cl}$ in Well $\mathrm{A} 38$ and $\mathrm{Ca}-\mathrm{Na}-\mathrm{Cl}$ in Wells A67 and A73. This type of groundwater has high sulfate contents, especially in Wells A67 and A73 that had the same TDS, $1299 \mathrm{mg} / \mathrm{L}$. However, the $\mathrm{Cl}$ concentrations in these three wells were not as high as the other wells and still within the water quality standards. In contrast, the Na contents were high and, therefore, exceeded the benchmark for safe water (i.e., $259-280 \mathrm{mg} / \mathrm{L}$ ). Sulfate in groundwater is likely the product of dissolved sulfide minerals (Muchamad et al., 2017) or reduced organic matters in marine environments or swamps in the past (Santosa, 2010).

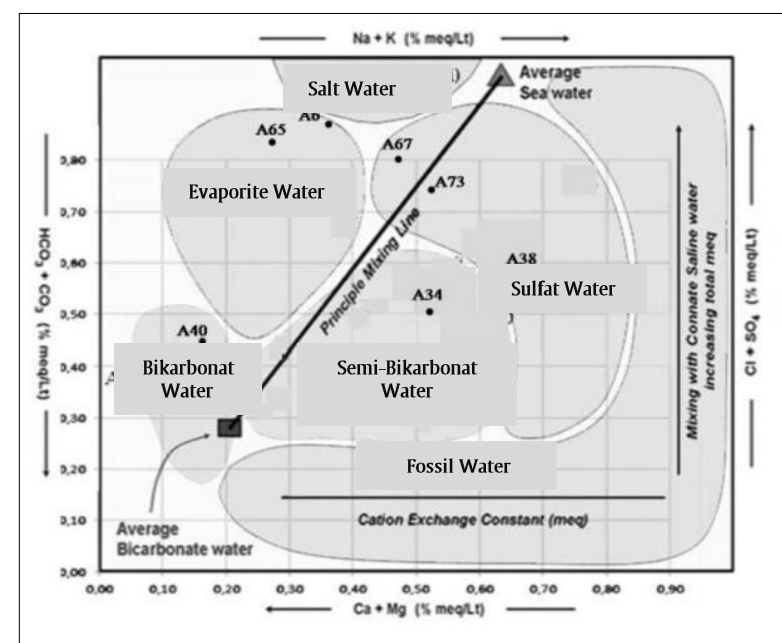

Fig 7. The Hydrogeochemical Facies of Groundwater in Jambakan Hamlet (Rectangular Piper Diagram 
Table 4. The Hydrochemical Facies of Groundwater in Jambakan Hamlet Based on Trilinear and Rectangular Piper Diagrams

\begin{tabular}{|c|c|c|c|}
\hline \multirow{3}{*}{ Water Wells } & \multicolumn{3}{|c|}{ Hydrochemical Facies } \\
\hline & \multicolumn{2}{|c|}{ Trilinear Piper Diagrams } & \multirow[t]{2}{*}{ Rectangular Piper Diagrams } \\
\hline & Types & Dominant Ions & \\
\hline A40 & Magnesium Bicarbonate & $\mathrm{Ca}-\mathrm{HCO}_{3}-\mathrm{Cl}$ & Type I (bicarbonate water) \\
\hline A45 & Magnesium Bicarbonate & $\mathrm{Ca}-\mathrm{HCO}_{3}$ & Type II (semi-bicarbonate water \\
\hline A34 & Mixed & $\mathrm{Ca}-\mathrm{Na}-\mathrm{HCO}_{3}-\mathrm{Cl}$ & Type II (semi-bicarbonate water \\
\hline A6 & Calcium Chloride & $\mathrm{Ca}-\mathrm{Na}-\mathrm{Cl}$ & Type III (evaporite water) \\
\hline A65 & Calcium Chloride & $\mathrm{Ca}-\mathrm{Cl}$ & Type III (evaporite water) \\
\hline A38 & Sodium Chloride & $\mathrm{Na}-\mathrm{HCO}_{3}-\mathrm{Cl}$ & Type IVb (sulfate water) \\
\hline A67 & Sodium Chloride & $\mathrm{Ca}-\mathrm{Na}-\mathrm{Cl}$ & Type IVc (sulfate water) \\
\hline A73 & Sodium Chloride & $\mathrm{Ca}-\mathrm{Na}-\mathrm{Cl}$ & Type IVc (sulfate water) \\
\hline
\end{tabular}

\section{Conclusions}

Several water quality parameters of groundwater in Jambakan Hamlet have exceeded their benchmarks, particularly in Wells A6, A34, A38, A65, A67, and A73. These parameters include TDS, EC, salinity, sodium, calcium, chloride, sulfate, magnesium, and hardness. Compared with these six wells, A40 and A45 have better groundwater quality. Brackish groundwater distribution cannot be modeled horizontally because salinity strongly depends on the rock layers at which the water wells are located. Geologically, the study area is unique as it has layers of fine materials or clay up to $70 \mathrm{~m}$ below the ground. The claystone is believed to be the source of the brackish groundwater. Also, within the depth of 0-70 m, there are layers of loose materials or alluviums, with a thickness of 1-2 $\mathrm{m}$, from the young rock formations of Mt. Merapi. Freshwater is found in these thin layers.

The scattered plots of major ions on the trilinear and quadrilateral Piper diagrams define the hydrochemicalfacies of groundwater in Jambakan Hamlet. Based on the trilinear Piper diagrams, there are four hydrochemical types of groundwater, namely magnesium bicarbonate, mixed type, calcium chloride, and sodium chloride. Meanwhile, based on the quadrilateral Piper diagrams, the groundwater has four hydrochemical types, namely Type I (bicarbonate water) in well A40, Type II (semi-bicarbonate water) in well A34 and A45, Type III (evaporative water) in well $A 65$ and A6, and Type IVb - IVc (sulfate water) in well A38 and A73.

\section{Acknowledgement}

This research is financially supported by the Institute of Research and Community Service (LPPM) Universitas Pembangunan Nasional (UPN) "Veteran" Yogyakarta, Indonesia under The Cluster Grant 2019. We also thank our colleagues and student assistance especially from the Environmental Engineering Department UPN Veteran Yogyakarta who totally supported this research.

\section{References}

Alaerts, G. dan Santika, S.S., 1987.MetodaPenelitian Air. Penerbit Usaha Nasional Surabaya, Surabaya.

Astuti, W., A. Jamali, dan M. Amin., 2006. Desalinasi Air Payau menggunakan Surfactant Modified Zeolite (SMZ). Proceedings, Seminar Nasional dan Temu Bisnis Zeolite V, Lampung.
Effendi, H., 2003. Telaah Kualitas Air bagi Pengelolaan Sumber Daya dan Lingkungan Perairan. CetakanKelima, PenerbitKanisius, Yogyakarta.

Fatoni, M., C. Muryani, and S. Nugraha, 2018. Studi Agihan Salinitas Airtanah Dangkal di Kecamatan Puring Kabupaten Kebumen Tahun 2016. JurnalGeoEco, Vol.4, No.1, pp. 77-87.

Muchamad, A.N., B.Y.CSS. Syah Alam, E.T. Yuningsih, 2017. Hidrogeokimia Airtanah pada Daerah Pantai: Studi Kasus Dataran Rendah Katak, Desa Sumber Agung, Kabupaten Banyuwangi. RISET Geologi dan Pertambangan, Vol. 27, No. 1, pp. 3946.

Mulyaningsih, S., Sampurno, Y. Zaim, D. J. Puradimaja, S. Bronto, and D. A. Siregar, 2006. Perkembangan Geologi pada Kuarter Awal sampai Masa Sejarah di Dataran Yogyakarta. JurnalGeologi Indonesia, Vol. 1, No. 2, pp. 103-113.

Novianto, A., E. Yogafanny, R. Ernawati, and W.W. Nandari, 2019. Brackish Water in The Jambakan Area: Where did They Come From? (Geoelectric and Geohydrology Analysis).Proceedings.

Rahardjo, W., 2000.TinjauanGeologi dan Paleogeografi Daerah DataranGantiwarno, antaraPrambanan Klaten, Jawa Tengah.Proceedings of Indonesian Association of Geologists, The $29^{\text {th }}$ Annual Convention, Bandung.

Santosa, Langgeng Wahyu, 2001.Hidrostratigrafi dan Hidrokimia Airtanah di Sekitar Rowo Jombor Kecamatan Bayat - Klaten. Majalah Geografi Indonesia, Vol. 15, No. 2, pp. 165 - 184.

Santosa, Langgeng Wahyu, 2010. Kajian Genesis Bentuk lahan dan Pengaruhnya Terhadap Hidrostratigrafi Akuifer dan Hidrogeokimia sebagai Geoindikator Evolusi Airtanah Bebas pada Bentang lahan Kuarter Kabupaten Kulonprogo Bagian Selatan, Daerah Istimewa Yogyakarta. (Disertasi). Fakultas Geografi Universitas Gadjah Mada, Yogyakarta.

Sari, T. R., 2019. Genesa Dan Pengolahan Airtanah Payau Sebagai Sumber Air Bersih Warga Desa Jambakan, Kecamatan Bayat, Kabupaten Klaten, Provinsi Jawa Tengah.(Bachelor Thesis). Universitas Pembangunan Nasional Veteran Yogyakarta, eprints.upnyk.ac.id/18533/.

Sugiyono, Sondang P., 2013. Metode Penelitian Pendidikan Pendekatan Kuantitatif, Kualitatif dan R \& D, Penerbit Alfabeta, Bandung.

Suharyadi, 1984. Geohidrologi, Fakultas Teknik Universitas Gadjah Mada, Yogyakarta. 
(C) 2016 Journal of Geoscience,

Engineering, Environment and

Technology. All rights reserved. This is

an open access article distributed under

the terms of the CC BY-SA License

(http://creativecommons.org/licenses/by-sa/4.0/). 